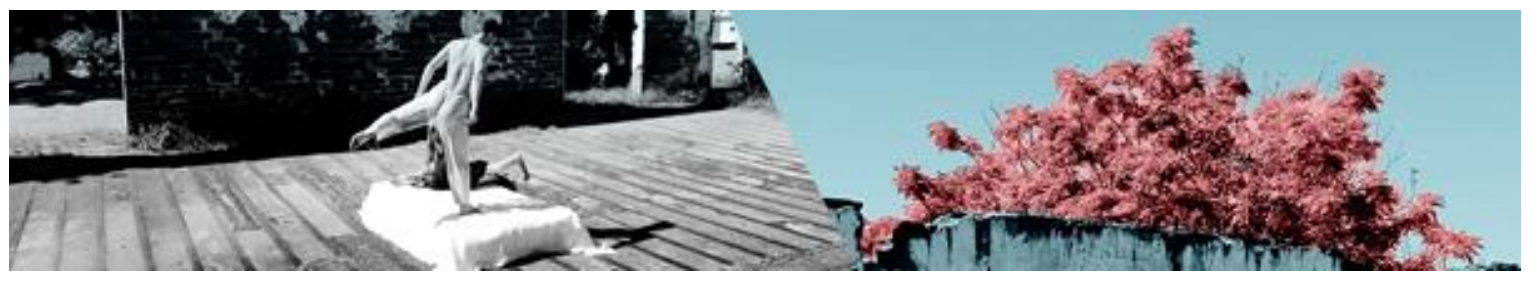

\title{
CORPOS ROUBADOS NOS SABERES DO ENSINO DE ARTE
}

\author{
Marina Maura de Oliveira Noronha ${ }^{l}$ \\ Marcos Antônio Bessa-Oliveira ${ }^{2}$
}

\begin{abstract}
Resumo: Os conceitos que delimitam corporeidades, lugares e culturas emergem do sistema moderno colonial. A partir disso, abordamos neste trabalho práticas docentes do estágio supervisionado em duas escolas públicas de Campo Grande-MS, obrigatoriedade da Graduação em Artes Cênicas-Licenciatura (UEMS), que se configuraram por dualismos no ensino de Arte, para (re)verificar e (re)significar corpos que dançam nas escolas. Tratamos as questões naquelas aulas por uma epistemologia outra, uma episteme cultural (GROSFOGUEL, 2008; FOUCAULT, 1987; HALL, 2005; HISSA, 2011) e por autoras que tratam da dança: Bertherat, Strazzacappa, Marques, Greiner e Miller. Queremos mostrar o valor dos corpos estudantis "dançarem" novas possibilidades de produção de saberes.
\end{abstract}

Palavra-chave: Corpo cênico pedagógico; Ensino de Arte; Escola.

\section{BODIES STOLEN IN ART TEACHING KNOWLEDGE}

\begin{abstract}
Concepts that delineate corporations, places, and cultures emerge from the modern colonial system. Concepts that delineate corporations, places, and cultures emerge from the modern colonial system. From this, we approach in this work teaching practices of the supervised stage in two public schools of Campo Grande-MS, compulsory degree in Performing Arts-Degree (UEMS), which were configured by dualism in art teaching, (to)verify and (to)mean bodies that dance in schools. We deal with the questions in those classes by a other epistemology, a cultural episteme (GROSFOGUEL, 2008; FOUCAULT, 1987; HALL, 2005; HISSA, 2011) and by authors dealing with dance: Bertherat, Strazzacappa, Marques, Greiner e Miller. We want to show the value of student bodies "dancing" new possibilities of knowledge production.
\end{abstract}

Keyword: Scenic pedagogical body; Art Teaching; School.

\footnotetext{
${ }^{1}$ Marina Maura de Oliveira Noronha é Graduada em Artes Cênicas - Licenciatura - e Aluna Especial no PROFEDUC - Programa de Mestrado Profissional em Educação - na UEMS - Universidade Estadual de Mato Grosso do Sul e Aluna Especial no PPGMel - Programa de Mestrado em Estudos de Linguagens da UFMS. É Membro do Grupo de Pesquisa NAV(r)E - Núcleo de Artes Visuais em (re)Verificações Epistemológicas - UEMS/CNPq e do NECC - Núcleo de Estudos Culturais Comparados - UFMS.

2 Marcos Antônio Bessa-Oliveira - Graduado em Artes Visuais e Mestre em Estudos de Linguagens pela UFMS - Universidade Federal de Mato Grosso do Sul, Doutor em Artes Visuais pelo IAR UNICAMP. É professor do curso de Graduação em Artes Cênicas (TEATRO e DANÇA) da e do PROFEDUCA - Programa de Mestrado Profissional em Educação - UEMS - Universidade Estadual de Mato Grosso do Sul - na Cadeira de Artes Visuais ministrando as disciplinas de História da Arte, Artes Visuais, Itinerários Científicos III, Arte e Cultura Regional, Arte Educação, Itinerários Científicos IV para os 1ํ, $3^{\circ}$ e $4^{\circ}$ anos do curso. É líder do Grupo de Pesquisa NAV(r)E - Núcleo de Artes Visuais em (re)Verificações Epistemológicas - UEMS/UEMS. É membro do NECC - Núcleo de Estudos Culturais Comparados - UFMS e do Núcleo de Estudos Visuais - UNICAMP.
}

NORONHA, Marina Maura de Oliveira; BESSA-OLIVEIRA, Marcos Antônio.Corpos roubados nos saberes do ensino de Arte. Revista da FUNDARTE, Montenegro, p.417-437, ano 19, № 37, Janeiro/Março.

Disponível em: http://.seer.fundarte.rs.gov.br/index.php/RevistadaFundarte/index> 30 de março de 2019. 


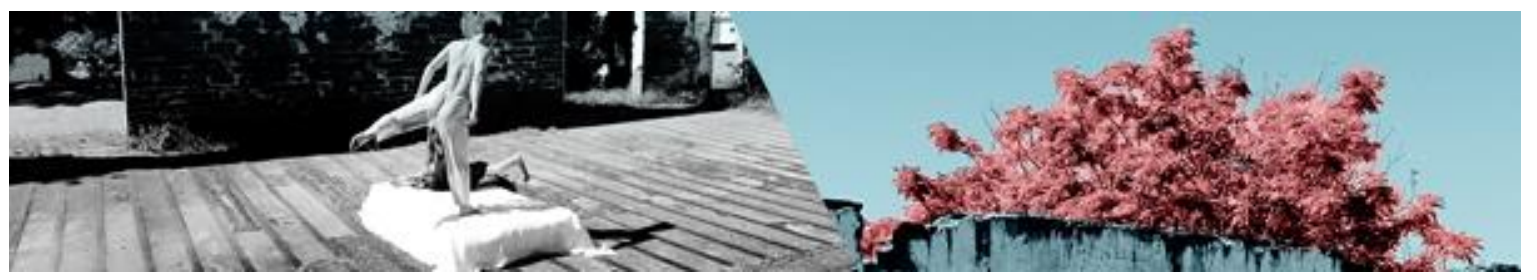

Introdução - Construção epistêmica do corpo (bio) cênico outro

Nosso corpo somos nós. É nossa única realidade perceptível. Não se opõe à nossa inteligência, sentimentos, alma. Ele os inclui e dá-lhes abrigo. Por isso tomar consciência do próprio corpo é ter acesso ao ser inteiro... pois corpo e espírito, psíquico e físico, e até força e fraqueza, representam não a dualidade do ser, mas sua unidade. (THÉRÈSE, 2010, p. 14).

O corpo transforma-se nas experivivências ${ }^{3}$, através de lampejos de racionalidade,e é, portanto, objetivo e tendencioso. O corpo é universo particular que, assim como os "astros" que estão em constante rotação, movimenta-se, colidindo com pessoas, lugares, crenças, culturas, política, forças e fraquezas diferentes: convergentes e divergentes. Nesse entremeio, o corpo busca, em cada encontro, outras formas de (re)conhecimento do espaço em que se encontra movendo e nas suas relações que o permeiam, e nessa prontidão são milhares de encontros acontecendo e vários por acontecer. Corpos esses, então, que para nós vão dançar - movem-se - todos os dias.

No seu dançar, o corpo "está constantemente adquirindo novos hábitos, novos saberes que provocam - nesse corpo - o surgimento de novos centros significativos: a dança cria novos centros de significação para o corpo" (DANTAS, 1999, p. 109). A dança propõe-nos pensar acerca dessa relação do corpo em movimento e a sua repercussão nos espaços em que estão situados e o quanto esses espaços estão intrínsecos nesses corpos. Pois, para nós, entende-se corpo (sujeito biográfico), espaço (geografia cultural), mover-se (conhecimentos específicos) - uma questão de biogeografia (BESSA-OLIVEIRA; NORONHA, 2018) como atitudes de compreender sujeitos, lugares e conhecimentos - como modos indissociáveis.

Dentro do ambiente escolar as experivivências em arte se desenvolvem da perspectiva de "um conhecimento corporificado, que se manifesta também como

\footnotetext{
${ }^{3}$ Partindo do corpo aqui em questão "O corpo é espaço/lugar de experivivências em que se misturam histórias, memórias e biografia (marcas) da diferença de diferentes modos." (BESSA-OLIVEIRA, 2018, p. 5).
}

NORONHA, Marina Maura de Oliveira; BESSA-OLIVEIRA, Marcos Antônio.Corpos roubados nos saberes do ensino de Arte. Revista da FUNDARTE, Montenegro, p.417-437, ano 19, no 37, Janeiro/Março.

Disponível em: http://.seer.fundarte.rs.gov.br/index.php/RevistadaFundarte/index> 30 de março de 2019. 


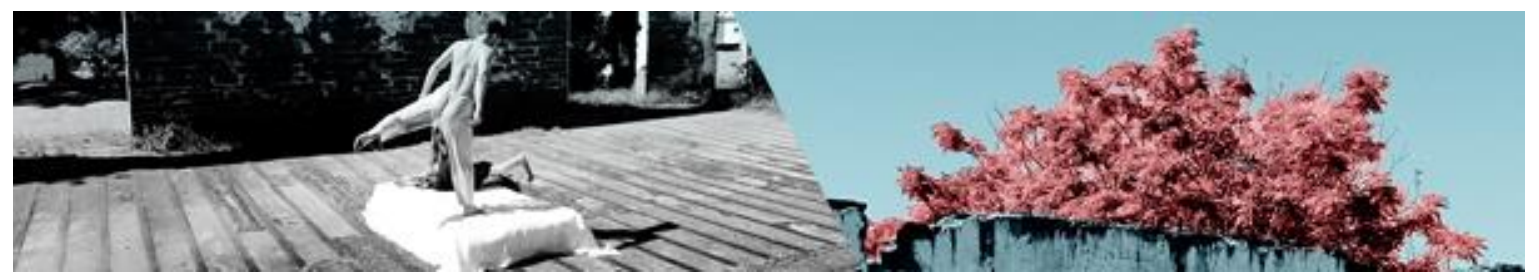

conhecimento processual e transversal, à medida que se compõe continuamente de múltiplos planos e aciona uma pluralidade de campos de conhecimento" (MENCARELLI, 2017, p. 5). Igualmente, já que a escola é este lugar de múltiplas possibilidades (sujeitos, lugares e conhecimentos) divergentes e convergentes, acontece com essas multiplicidades de conhecimentos que os corpos possuem, através de suas subjetividades, que na maioria das vezes são abandonados por conta do tradicionalismo, o que determina uma "não-movimentação" corpórea reconhecida como conhecimento/disciplina.

\begin{abstract}
As crianças educadas e comportadas eram aquelas que simplesmente não se moviam. O modelo escolar-militar da primeira metade do século XX era aplicado desde o momento em que a criança chegava na escola. As filas por ordem de tamanho para se dirigirem às salas de aula, o levantar-se cada vez que o diretor ou supervisor de ensino entrava na sala etc. Atualmente, são raros os estabelecimentos escolares que mantêm este tipo de atitude, encontrado ainda apenas em escolas de cunho religioso e em algumas escolas públicas de cidades pequenas do interior do estado. Nas escolas da rede pública das grandes cidades, esta realidade já não existe. Apesar da ausência destas atitudes disciplinares, a ideia do não-movimento como conceito de bom comportamento prevalece. Muitas escolas aboliram as filas e os demais símbolos de respeito a diretores e professores; no entanto, foram criadas outras maneiras de se limitar o corpo. O movimento corporal sempre funcionou como uma moeda de troca. (STRAZZACAPPA, 2001, p. 70).
\end{abstract}

Infelizmente, a educação não se atualiza aos corpos que estão em constantes transformações, como no caso dos corpos dos "agoras". Os corpos ainda são histórias (históricos) contadas como nossas nas escolas. Diante disso, é preciso compreender o ensino de Arte no Brasil. Ainda que em um brevíssimo histórico, é preciso! Esse estudo nos serve como forma de não incorrer nos erros postos desde sempre, desde 1500. Por processos históricos trazidos pelo pensamento moderno, eurocêntrico, por exemplo, ainda temos Histórias que refletem na pedagogia e nas práticas de ensino nas escolas da contemporaneidade que viajam de lugares para lugares em todos os tempos.

Por isso, o ensino de Arte hoje tem emergências, e são múltiplas. No caso da Dança é preciso (re)configurar os corpos, pensar num corpo (contra)modelo estabelecido desde o século XV. Um corpo não mais disciplinar como já nos é

NORONHA, Marina Maura de Oliveira; BESSA-OLIVEIRA, Marcos Antônio.Corpos roubados nos saberes do ensino de Arte. Revista da FUNDARTE, Montenegro, p.417-437, ano 19, № 37, Janeiro/Março.

Disponível em: http://.seer.fundarte.rs.gov.br/index.php/RevistadaFundarte/index> 30 de março de 2019. 


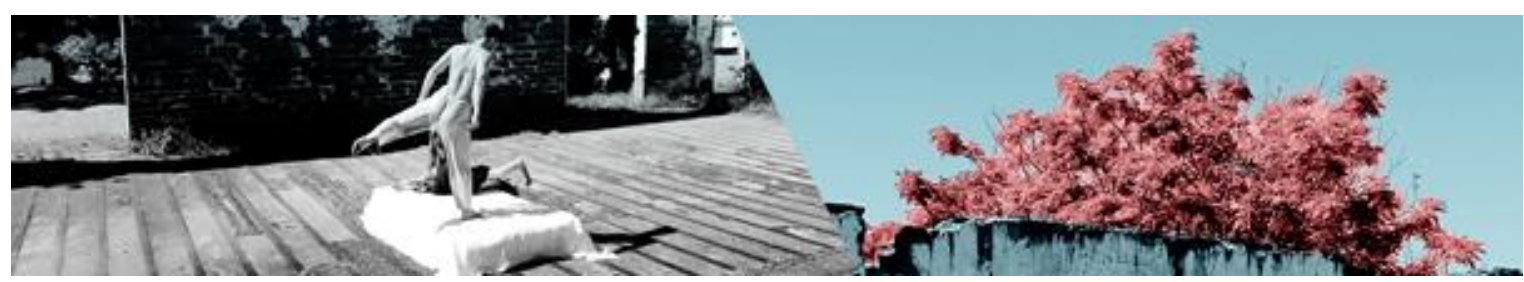

(im)posto pelos colonizadores. O corpo pensado neste trabalho não é um corpo estático, o corpo do estudante pensado aqui si-move-se (BESSA-OLIVEIRA, 2017): tanto si-move para onde e como quer, quanto move-se por conta do seu contexto sociocultural e político. Partindo dessa perspectiva de Autor Suprido, o corpo do estudante é entendido também como um gerador constante de troca/transmissão de conhecimentos, assim como é um corpo que consegue "[...] pensar dançando e dançar pensando" (MARQUES, 1998, p. 71).

O corpo dançante (do estudante, por exemplo) neste trabalho é o corpo cênico pedagógico ${ }^{4}$ (NORONHA; BESSA-OLIVEIRA, 2015), um corpo situado fora do seu saber disciplinar moderno para os espaços da sala de aula. Por muito tempo, o corpo veio sendo visto e sentido pelo olhar do outro, em muitos casos ainda o é; principalmente nas escolas, o corpo não disciplinado é visto como um corpo desconhecido que parece não fazer parte do sujeito/contexto. Um corpo inexistente ${ }^{5}$. Por isso, tem-se muito para discutir no ensino de artes nas escolas da atualidade, qual corpo ocupa as aulas de Arte e de qual saber esse corpo é abordado?

Considerando as experivivências corporais vivenciadas no estágio supervisionado obrigatório do Curso de Artes Cênicas-Licenciatura (2017/2018) da UEMS-UUCG, discutirei como se deram os processos didático-pedagógicos e metodológicos, tomando do corpo cênico pedagógico como âncora epistêmica, nas aulas teóricas e práticas de Arte nas escolas por onde estagiei com o meu próprio corpo cênico pedagógico ${ }^{6}$. A ideia primeira para o entendimento do corpo cênico

\footnotetext{
${ }^{4}$ A conceituação do corpo cênico pedagógico está assentada na formulação que toma da ideia de espaços vistos como não disciplinares ocupados por corpos não reconhecidos pelo saber disciplinar, como corpos que dançam as danças das academias: sejam elas do conhecimento, sejam as academias de preparação física.

${ }^{5}$ Quando falamos isso, queremos contemplar a ideia de um corpo que existe e parece não existir ao mesmo tempo.

${ }^{6} \mathrm{Na}$ arguição do Prof. Dr. Edgar Cézar Nolasco, que participou da minha banca de defesa do trabalho de conclusão de curso, o professor pontuou que pensando o corpo em cena que sente, que pensa e no caso do professor, ensina, a partir de Roland Barthes que pensava na escritura, o corpo do professor é Aquele que acaba as frases. Por conseguinte, o professor Nolasco sinalizou: Podemos pensar então o professor como aquele que acaba os movimentos ou aquele que aponta a direção dos movimentos. Assim, os estudantes nas aulas são levados a um autoconhecimento de si e do meu

NORONHA, Marina Maura de Oliveira; BESSA-OLIVEIRA, Marcos Antônio.Corpos roubados nos saberes do ensino de Arte. Revista da FUNDARTE, Montenegro, p.417-437, ano 19, № 37, Janeiro/Março.

Disponível em: http://.seer.fundarte.rs.gov.br/index.php/RevistadaFundarte/index> 30 de março de 2019.
} 


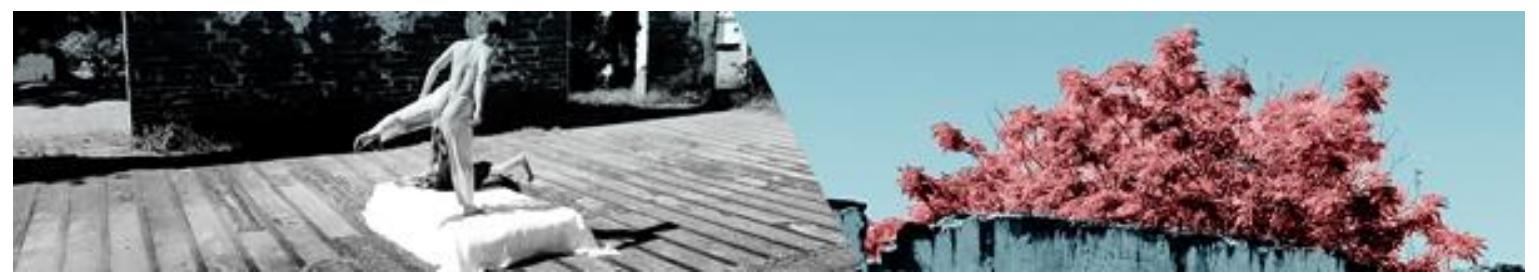

pedagógico foi legitimar o corpo biogeográfico (BESSA-OLIVEIRA, 2016) dos estudantes que dançam e pensam juntos, por isso si-movem-se, e que são corpos produtores de saberes para o ensino de artes na disciplina de Arte. ${ }^{7}$ Saberes que estão e são atravessados pela prática, a teoria e a pesquisa em dança/arte, pois podemos compreender também, assim, outros corpos que transitam dentro e fora dos muros da escola que também partilham desses/seus saberes. Sobre essa visão epistêmica de corpos outros Bessa-Oliveira pontua que:

Agora é possível que o ensino em todas as disciplinas, e não só de artes, faça formulações metodológicas entre os conteúdos mais tradicionais com a realidade: grafite, Hip Hop, Funck, outras tantas expressões pertencentes ao cotidiano e as verdadeiras experiências artísticas dos alunos. Isso é possível de se pensar considerando que, apesar do ensino de modo geral ainda ser muito disciplinar, o professor não é "obrigado", dependendo de sua postura crítica e metodológica, segui-los como os únicos a fomentar suas aulas. (BESSA-OLIVEIRA, 2010, p. 136).

Nesse sentido, passando pelo ensino de Arte na atualidade, em um primeiro momento, me deparei durante as aulas ministradas no estágio com uma multiplicidade de corpos nas salas de aula, cada um com a sua particularidade, que não eram contemplados pelo saber e conteúdo disciplinares. Considerando esses corpos nesse espaço, portanto, propus, a partir das conceituações que venho desenvolvendo em projetos de pesquisas ao longo do meu curso de graduação, trabalhar o corpo cênico pedagógico, em duas escolas públicas do Mato Grosso do Sul ${ }^{8}$. Num segundo momento, tendo em vista o contexto encontrado, os corpos cênicos pedagógicos dos estudantes e o meu corpo-professor por extensão foram abordados a partir de uma epistemologia outra para designar corpos outros ${ }^{9}$ como

próprio corpo por extensão. Por isso, através da palavra e do trabalho com o autoconhecimento do corpo nas aulas de arte, o professor Nolasco sugeriu a ideia de tomar o corpo como biopedagógico.

7 Cabe aqui uma breve explicação: falamos em ensino de artes porque os estudantes nas escolas deveriam ter acesso às diferentes linguagens da arte (Artes Visuais, Dança, Música e Teatro, especialmente, porque estão nos documentos legisladores, mas nas demais linguagens possíveis também).

8 Uma dessas foi a Escola Estadual Prof ${ }^{a}$ Hilda de Souza Ferreira, onde realizei o estágio obrigatório do ensino fundamental I entre as turmas do $6^{\circ}$ ao $8^{\circ}$ anos, e outra foi a Escola Estadual 26 de Agosto realizando o estágio supervisionado com as turmas do $1^{\circ}$ ao $3^{\circ}$ anos do ensino médio.

${ }_{9}$ Para condução/transposição na prática para a compreensão de como se deu essa episteme outra, ou seja, designar corpos outros, foi partindo do conteúdo da professora de Arte - habilitada em Artes

NORONHA, Marina Maura de Oliveira; BESSA-OLIVEIRA, Marcos Antônio.Corpos roubados nos saberes do ensino de Arte. Revista da FUNDARTE, Montenegro, p.417-437, ano 19, № 37, Janeiro/Março.

Disponível em: http://.seer.fundarte.rs.gov.br/index.php/RevistadaFundarte/index> 30 de março de 2019. 


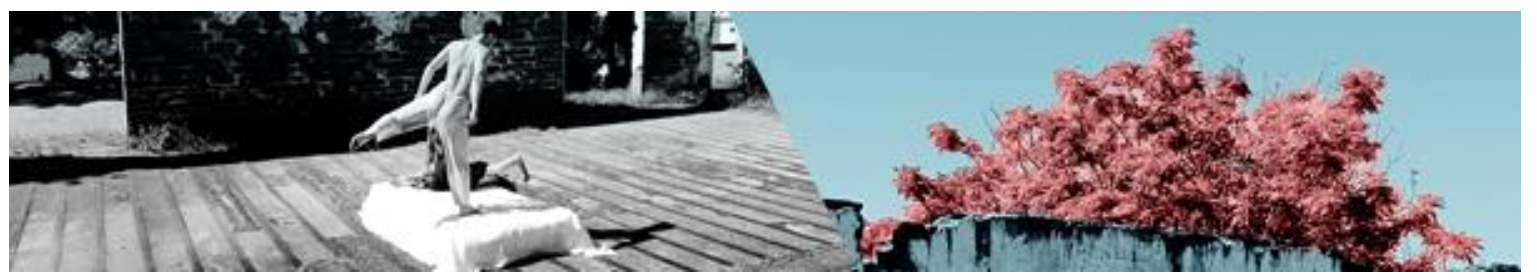

produtores de conhecimentos nos espaços das salas de aula, partindo das especificidades dos próprios estudantes.

Partindo desse termo epistemologia outra, a ideia sobre esses corpos está exatamente em poder (re)verificar e (re)significar corpos outros nas salas de aula, a exemplo de como o corpo tradicional "escolar" se (re)configura em dança ${ }^{10}$. Por isso, tomo de outras perspectivas como produtoras de conhecimentos, diferentes daquela estrutura dicotômica do "corpo sentado", corpos condicionados às cadeiras e mesas dos estudantes como únicos lugares ocupáveis. Uma ideia de corpo que ainda mantém seus "dispositivos disciplinar" (FOUCAULT, 1987, p. 221) de controle do corpo, do movimento e do espaço da sala de aula, tornando os corpos dos estudantes enrijecidos por um padrão de corpo moderno colonizador. Nesse sentido, igualmente, Foucault evidencia a "docilidade" existente e incompreendida dos corpos para/nas aulas disciplinares:

A disciplina fabrica assim corpos submissos e exercitados, corpos "dóceis". A disciplina aumenta as forças do corpo (em termos econômicos de utilidade) e diminui essas mesmas forças (em termos políticos de obediência). Em uma palavra ela dissocia o poder do corpo; faz dele por um lado uma "aptidão", uma "capacidade" que ela procura aumentar; e inverte por outro lado a energia, a potência que poderia resultar disso, e faz dela uma relação de sujeição estrita. (FOUCAULT, 1987, p. 164-165).

Deste modo, a reluta do sistema cartesiano (Penso, logo existo!) impera nas salas de aula no controle do movimento dos corpos, mantendo-os "dóceis" e domados nas escolas. Isso reflete direto na tensão dos estudantes diante das

\footnotetext{
Visuais - nas aulas, com a atividade do ciclo cromático das cores. Propus uma experivivência aos estudantes a partir de recortes em papel coloridos (cores presentes no círculo cromático) de mãos e pés fixados ao chão e na parede, e para o desenvolvimento corporal utilizei os níveis - alto, médio e baixo (LABAN, 1978) - onde, para compor os movimentos, os estudantes tinham que alcançar as marcas das cores de mãos e pés impressas postas no chão e na parede em diferentes níveis de dificuldades. Os estudantes alcançaram suas percepções corporais, um conteúdo já experienciado por mim nas aulas práticas de algumas disciplinas da universidade no curso de Artes Cênicas, agora transposto a partir de Artes Visuais. Decorrente da percepção do estudante com o próprio corpo o entendimento também do ciclo cromático de cores do conteúdo de Artes Visuais foi alcançado. Isso é conhecimento a partir do próprio conhecimento que se relaciona com conhecimentos consolidados.

$10 \mathrm{O}$ corpo tradicional (re)significa-se no corpo que dança através das técnicas aprendidas na universidade, mas valendo do corpo do estudante para fazể-los reconhecer que seus movimentos já são conhecimentos de seus próprios corpos. Ou seja, para dançar não é preciso dominar técnica alguma, mas reconhecer seu próprio corpo como dança.
}

NORONHA, Marina Maura de Oliveira; BESSA-OLIVEIRA, Marcos Antônio.Corpos roubados nos saberes do ensino de Arte. Revista da FUNDARTE, Montenegro, p.417-437, ano 19, № 37, Janeiro/Março.

Disponível em: http://.seer.fundarte.rs.gov.br/index.php/RevistadaFundarte/index> 30 de março de 2019. 


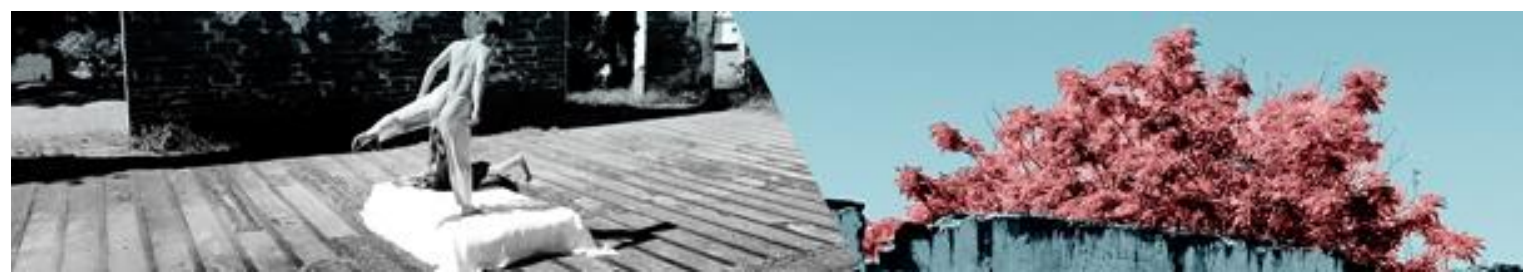

propostas de si-moverem-se nos espaços das salas de aula. O estudante não compreende que está aprendendo, muito menos que esteja produzindo conhecimento a partir de seus próprios conhecimentos. Neste caso, os estudantes só entendem que estão aprendendo o conteúdo, que é disciplinar, se estiverem sentados em suas respectivas cadeiras e com o caderno e lápis sobre a mesa em infinitas anotações das lousas repletas de histórias alheias. "Estes conceitos precisam de ser descolonizados e tal só pode ser conseguido por meio de uma epistemologia descolonial que assume abertamente uma geopolítica e uma corpopolítica do conhecimento descoloniais". (GROSFOGUEL, 2008, p. 48-49).

Pensar essa discussão partindo da perspectiva epistêmica descolonial é urgente, pois visa considerar corpos que não têm o reconhecimento nos espaços da escola. A realidade é que só uma epistemologia outra pode dar conta de trazer possibilidades outras no ensino, rompendo com o pensamento abissal que delimita com uma cratera infindável o campo investigativo dos estudantes nas escolas: um abismo que estabelece nas margens da dualidade, história, geografia e ciência privilegiados, por tempo $\mathrm{X}$, diferentes sujeitos, arte, cultura e conhecimentos múltiplos. E foi partindo dessas perspectivas investigativas do próprio corpo que o estudante chegou ao seu autoconhecimento - do seu corpo como seu apreendendo, com seu corpo-imagem, como corpo cênico pedagógico nas aulas, como "novas" possibilidades de aprendizados.

Para melhor compreensão da temática do corpo cênico pedagógico nas salas de aula de Arte, é necessário uma pedagogia libertadora a la Paulo Freire, pois esta prática de liberdade pode ser uma forma de divulgar, através do corpo que dança do estudante, uma visão libertadora de si próprio, sendo a dança pensada para todos; independente do contexto sociocultural de cada um, o corpo dançante nas aulas tornam-se condutores na formação social, cultural e política do sujeito/estudante que, por conseguinte, afetará também sua condição econômica. Um corpo que simove-se, não apenas na dança, mas na vida, pode ser um corpo que trabalha, que anda, que vive, que sabe ser, sentir e saber sua própria condição de sujeito que produz e não (re)produz.

NORONHA, Marina Maura de Oliveira; BESSA-OLIVEIRA, Marcos Antônio.Corpos roubados nos saberes do ensino de Arte. Revista da FUNDARTE, Montenegro, p.417-437, ano 19, no 37, Janeiro/Março.

Disponível em: http://.seer.fundarte.rs.gov.br/index.php/RevistadaFundarte/index> 30 de março de 2019. 


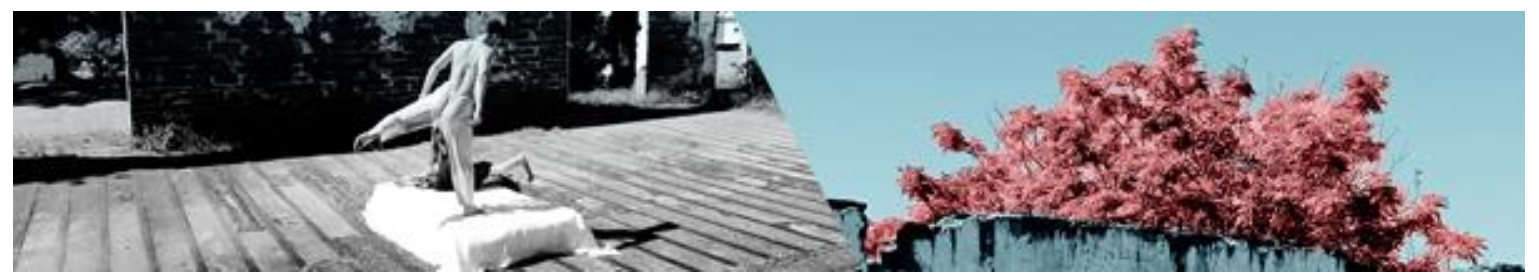

O corpo cênico pedagógico do estudante, partindo dessa prática de liberdade na educação, possibilita ainda o melhor entendimento desse corpo a partir das suas próprias experivivências culturais. Por isso, os corpos dos estudantes, através de um olhar atualizado no estágio supervisionado, foram estimulados e provocados nas aulas por outros saberes que, por conseguinte, registrou-os como corpos produtores de arte, cultura e conhecimento através da própria arte. Pois, o corpo biogeográfico do estudante -bio-sujeito, geo-espaço, grafia-narrativas- passou a dançar a partir das suas experivivências, apreendendo as propostas pedagógicas através da sua narrativa e também ensinando/estimulando a si e ao outro diante do seu próprio corpo-discurso nas aulas. O corpo cênico pedagógico é um corpo que tem voz e vez.

Assim, os estudantes aprenderam, com a proposta, da aula a dizer através do corpo, promovendo o reconhecimento de si, do outro e do contexto no seu próprio espaço-corpo. Lugares e corpos esses que o sistema escolar ainda não reconhece. Nesse sentido, as aulas geraram "[a] construção de uma epistemologia que parte de narrativas nem sempre explícitas do corpo em suas relações com o ambiente" (GREINER, 2017, p. 11). Para isso foi e ainda é preciso permitir que os corpos (re)existam ao/no seu lugar de fala. Para que assim esses cheguem a seus autorreconhecimentos, da sua autorrepresentação identitária e do seu respeito próprio em relação ao outro, dentro ou fora dos espaços da sala de aula. Por isso, deixa o corpo falar!

\section{Estagiando corpos dos saberes no ensino de Artes}

Durante a preparação do estágio supervisionado, a ideia principal emergiu a fim de que se conseguisse elaborar aulas que fossem possibilidades melhores para compreensão de um saber outro através do corpo que ensina, do corpo que pratica e do corpo que apreende o ensino de Arte na escola; os corpos dos estudantes, portanto, sendo pensados e conduzidos nas suas especificidades pelo corpo cênico pedagógico. Por conseguinte, corpos re(des)cobertos para um novo saber,

NORONHA, Marina Maura de Oliveira; BESSA-OLIVEIRA, Marcos Antônio.Corpos roubados nos saberes do ensino de Arte. Revista da FUNDARTE, Montenegro, p.417-437, ano 19, no 37, Janeiro/Março.

Disponível em: http://.seer.fundarte.rs.gov.br/index.php/RevistadaFundarte/index> 30 de março de 2019. 


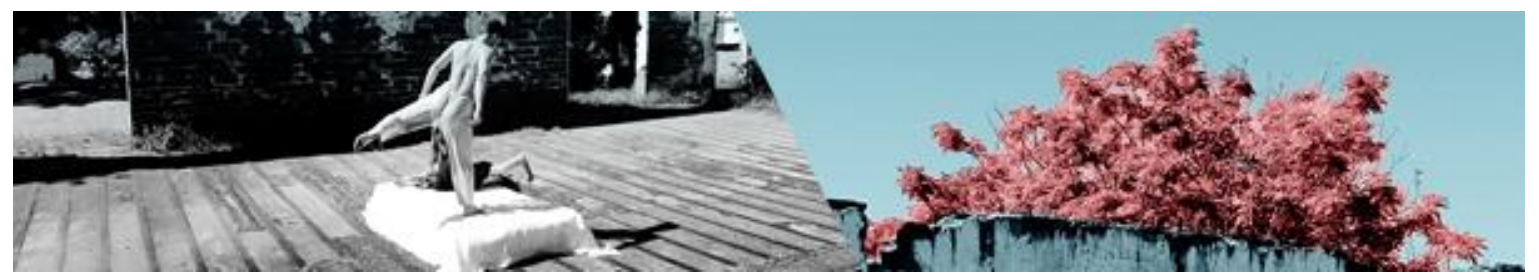

adquirindo autonomia e liberdade com o seu corpo para criar, pensar, sentir, agir, apreender e ensinar a partir dos seus próprios movimentos corporais.

Consequentemente, partindo dessas experivivências no estágio com o corpo cênico pedagógico dos estudantes, obtive resultados inimagináveis através da (re)verificação epistêmica atravessada pela prática, pela teoria e pela pesquisa em artes nas aulas. Esses resultados todos estão ancorados pelas orientações do Prof. BESSA-OLIVEIRA, com o qual vim desenvolvendo estudos e pesquisas ao longo da graduação, bem como venho desenvolvendo este estudo, e fazendo parte, como membro, do grupo de pesquisa $\mathrm{NAV}(\mathrm{r}) \mathrm{E} / \mathrm{UEMS}$ coordenado pelo professor. Tal envolvimento com a pesquisa foi bastante válido para colocar em prática o corpo cênico pedagógico do estudante nessa troca/transmissão com meu corpo de professora, que também faz parte dessa discussão. Um corpo proposto como produção de conhecimento para o ensino de dança nas salas de aula.

Estagiando nas duas escolas públicas de Mato Grosso do Sul, percebi que ambas se valem fortemente de uma linguagem específica: a linguagem das Artes Visuais, que na maioria das escolas é quase soberana para pensar o ensino de artes ainda hoje. Cheguei a essa conclusão após passar pela Escola Estadual Prof ${ }^{a}$ Hilda de Souza Ferreira no ensino fundamental II, entre as turmas do $6^{\circ}$ ao $8^{\circ}$ anos, da professora $1^{11}$ que conduzia suas aulas a partir da História da Arte, exclusivamente das Artes Plásticas. Por conseguinte, quando estagiei na disciplina de Arte na Escola Estadual 26 de Agosto, com as turmas do $1^{\circ}$ ao $3^{\circ}$ anos do ensino médio, ministrada pela professora 2 , identifiquei que esta tinha como repertório de suas aulas a Pintura Rupestre chegando até a Arte Visual Contemporânea

As experivivências com os corpos dos estudantes alteraram-se com 0 atravessamento de uma epistemologia outra pensada para as aulas. Esta postura docente epistêmica possibilitou a construção do corpo cênico pedagógico ao

\footnotetext{
11 Optei por manter o anonimato das respectivas professoras, a fim de priorizar a leitura crítico-teórica e epistêmica que prefiro fazer das minhas próprias aulas no estágio supervisionado. A ideia é que mantendo sem evidenciar o nome das pessoas envolvidas no processo, estudantes e professores, entendo que posso fazer argumentações mais pertinentes em relação às práticas docentes dos respectivos professores nas escolas. Não é uma pura questão de omissão para produzir crítica infundada.
}

NORONHA, Marina Maura de Oliveira; BESSA-OLIVEIRA, Marcos Antônio.Corpos roubados nos saberes do ensino de Arte. Revista da FUNDARTE, Montenegro, p.417-437, ano 19, no 37, Janeiro/Março.

Disponível em: http://.seer.fundarte.rs.gov.br/index.php/RevistadaFundarte/index> 30 de março de 2019. 


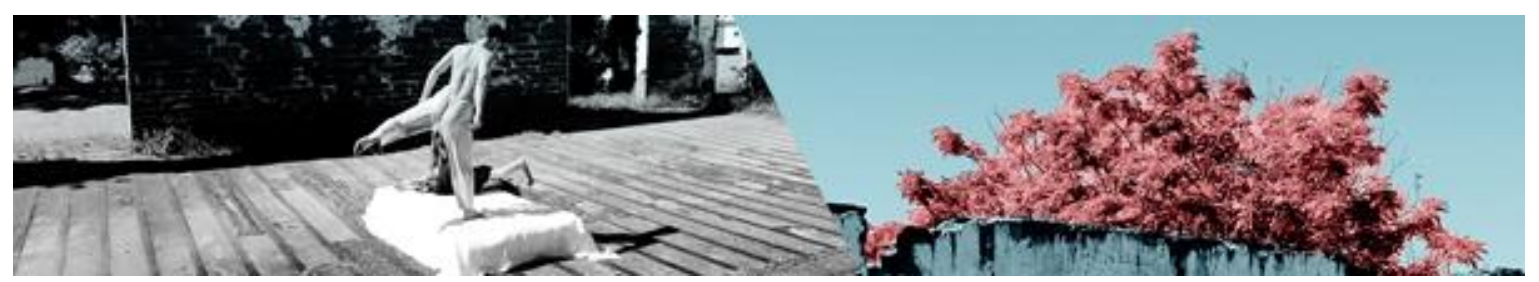

estudante, permitindo-o "[...] a reflexão [do seu corpo] sobre o ensino da dança em si, pautado na experiência do sujeito, o eu-corporal, o soma, com toda sua gama de complexidades" (MILLER, 2014, p. 101). Com essa proposta docente o corpo cênico pedagógico do estudante proporcionou também a retroalimentação das linguagens Artes Visuais $x$ Artes Cênicas, e vice-versa, promovendo aos corpos a troca "merecida" de conhecimentos para ambos os envolvidos, estudantes e professores nos espaços de ensino". Ou seja, os conteúdos de Artes Visuais - estudo de cor, movimentos artísticos na pintura, entre outros - foram muito mais facilmente transpostos para as Artes Cênicas.

Igualmente, com a observação participativa dos professores regentes 1 e 2 nas aulas propostas, puderam experivivenciar com o corpo cênico pedagógico dos estudantes o processo de (re)significação dos corpos. Um corpo que foi re(des)cobrindo das tradições postas nas aulas, porque passaram a se sentir estimulados e provocados a dançar a partir da escuta do próprio corpo conduzidos pelo seu corpo memória (MILLER, 2014). O estudante, assim, configurou-se no corpo-imagem cênico pedagógico e acabou sendo levado à compreensão de que outros tantos corpos o habitam. Quer dizer, o estudante, através da compreensão do seu próprio corpo como produtor de conhecimento, também reconhece que seu corpo-identitário é formado pelo contexto - outros corpos - que o cerca.

Logo, diante da complexidade do tema, acaba sendo bastante importante (re)pensar também a forma(ação) docente nas aulas de Arte para que se faça valer a possibilidade de outros saberes com o corpo em movimento na escola: o corpo que ensina-dança, pratica-dança e o corpo que aprende-dança porque si-move-se, portanto, um corpo que pensa-dança, logo existe! Com isso, o corpo cênico pedagógico nas minhas aulas de Arte se configurou como uma grande ponte, tanto para o aluno, como para o professor, diante de uma epistemologia outra nas salas de aula, promovendo atravessamentos entre os (nossos) corpos ${ }^{12}$. Do mesmo modo, a prática docente, a partir do corpo cênico pedagógico nas aulas, permitiu entender

\footnotetext{
${ }^{12} \mathrm{~A}$ importância da relação/transferência do meu corpo professor com o do aluno e o corpo do outro. Tomo do fazer-se corporal construído na condução da prática, na experiência da prática e na informação teórica. Gerando troca de experivivências como conhecimento e autoconhecimento.
}

NORONHA, Marina Maura de Oliveira; BESSA-OLIVEIRA, Marcos Antônio.Corpos roubados nos saberes do ensino de Arte. Revista da FUNDARTE, Montenegro, p.417-437, ano 19, № 37, Janeiro/Março.

Disponível em: http://.seer.fundarte.rs.gov.br/index.php/RevistadaFundarte/index> 30 de março de 2019. 


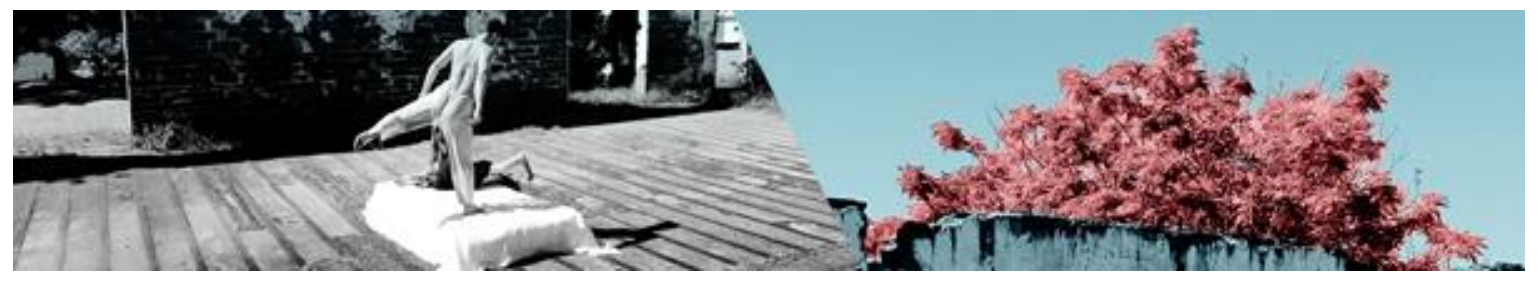

que o aprendizado a partir do corpo gera novos conhecimentos (no corpo), e estes são atravessados pelas diferentes linguagens que podem abrir ainda mais os saberes através das artes nas suas múltiplas possibilidades.

\section{Que ensino de artes encontramos nas escolas? Um saber roubado!}

A realidade encontrada nos estágios supervisionados realizados nos espaços das escolas públicas de Campo Grande/MS é a presença das imposições que tangem o presente do ensino de Arte; mesmo nas situações em que o ensino das artes estão "amparados" por documentos oficiais brasileiros que estabelecem a importância do ensino de Arte respeitando as especificidades das linguagens da Música, Artes Visuais, Teatro e Dança. Essa forma de aula ainda é deficiente como outras várias questões presentes no ensino de Arte. Os estudantes são conduzidos através de pedagogias ainda tradicionalistas (im)postas por um saber disciplinar que visa uma padronização do ensino para os corpos das salas de aulas. E algumas mudanças educacionais estão sendo redefinidas por novas leis que vêm sendo construídas e praticadas muito lentamente na prática cotidiana das escolas, distanciando-se da metodologia que deveria ser ideal: por exemplo, corpo e cultura, no ensino de dança, serem pensados e caminharem sempre juntos.

A lei de Diretrizes e Bases para a Educação Nacional (LDB) (1996) é clara ao sinalizar o ensino de Arte como componente curricular no ensino formal, partindo das quatro linguagens: Artes Visuais, Teatro, Dança e Música. Desta forma, nos corpos dos estudantes atravessados por corpos que partem da linguagem da Dança (Artes Cênicas) fica evidente a importância do diálogo da arte com o meio do sujeito/estudante no mundo. De fato deveria existir uma relevância maior do entendimento do conjunto para os outros envolvidos nos espaços da escola sobre a compreensão do corpo como forma de ensino e aprendizagem literal para as aulas de artes. Por isso, "[...] diretores, supervisores e professores de escola devem se conscientizar de que aula de arte não se resume a atividades de desenho e pintura e de que o ensino de arte é parte integrante da formação do cidadão". (STRAZZACAPPA, 2003, p. 79).

NORONHA, Marina Maura de Oliveira; BESSA-OLIVEIRA, Marcos Antônio.Corpos roubados nos saberes do ensino de Arte. Revista da FUNDARTE, Montenegro, p.417-437, ano 19, no 37, Janeiro/Março.

Disponível em: http://.seer.fundarte.rs.gov.br/index.php/RevistadaFundarte/index> 30 de março de 2019. 


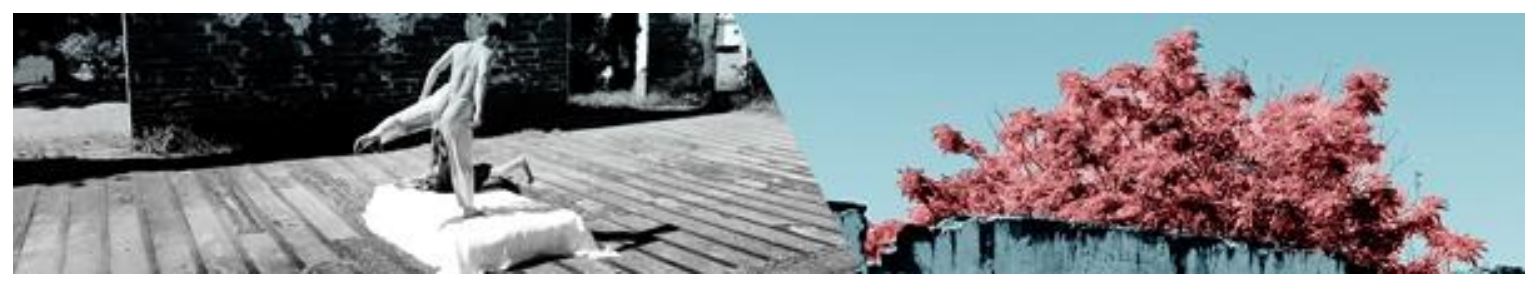

Considerando os corpos no estágio, a ideia não foi desvinculá-los de qualquer saber posto do ensino de Arte, mas (re)significá-los como corpos cênicos pedagógicos que têm o objetivo de construção de novos sujeitos nas escolas, corpos (cênicos) que atravessam e vivem em estado de fronteiras ${ }^{13}$ (BESSAOLIVEIRA, 2018). Colocando em prática, assim, os corpos dançantes dos estudantes a partir do entendimento de si e também do outro, amparados por uma epistemologia que valida corpos que dançam hoje nas suas diferenças. Atrelado a tudo isto Isabel Marques (2003) pontua que "[o] corpo em movimento, portanto, assume papel fundamental hoje em dia, e a dança enquanto forma de conhecimento torna-se praticamente indispensável para vivermos presentes, críticos e participantes em sociedade" (MARQUES, 2003, p. 23).

llustro, assim, a compreensão e a reflexão do corpo cênico pedagógico do estudante como produtor de arte, cultura e conhecimento, um corpo (re)existente para as aulas de artes da atualidade. De tal modo, os corpos dos estudantes foram conduzidos ${ }^{14}$ nas aulas do estágio supervisionado por teóricos que sustentam a discussão cultural15 sobre práticas e produções culturais de lugares (corpos) desconsiderados (GROSFOGUEL, MIGNOLO, HALL, HISSA), e alguns outros que discutem corpos outros como produtores dos saberes nos espaços do ensino de Arte. Tal prática é a forma epistêmica para o estudante apreender-sentindo nas aulas de Dança, por exemplo, que permite a emergência de corpos cênicos pedagógicos descolonizados.

Por meio de uma epistemologia outra o corpo cênico pedagógico dos estudantes, na verdade os vários corpos (cênico-pedagógicos) foram (re)flexionados nas aulas, levado a compreensão primeira do olhar do estudante para seu próprio

\footnotetext{
13 "Portanto, falamos aqui de corpos por/em fronteiras biogeográficas como contranarrativos, aos discursos universais hegemônicos, que geram arte, cultura e conhecimentos das suas diferenças coloniais." (BESSA-OLIVEIRA, 2018, p. 5).

${ }^{14} \mathrm{~A}$ ideia de corpos conduzidos nesse trabalho é exatamente proporcionar ao estudante reconhecerse ou reconhecer seu próprio corpo a partir de si como um corpo que pode dançar. Não falamos em condução de conteúdo pronto para fazer reconhecido em corpos com construções outras.

15 Para o entendimento dos estudos culturais que também perpassa nosso estudo vale saber que "Os Estudos Culturais se aproveitam de quaisquer campos que forem necessários para produzir 0 conhecimento exigido por um projeto particular." (NELSON; TREICHLER; GROSSBERG, 1995, p. 9).
}

NORONHA, Marina Maura de Oliveira; BESSA-OLIVEIRA, Marcos Antônio.Corpos roubados nos saberes do ensino de Arte. Revista da FUNDARTE, Montenegro, p.417-437, ano 19, ํo 37, Janeiro/Março.

Disponível em: http://.seer.fundarte.rs.gov.br/index.php/RevistadaFundarte/index> 30 de março de 2019. 


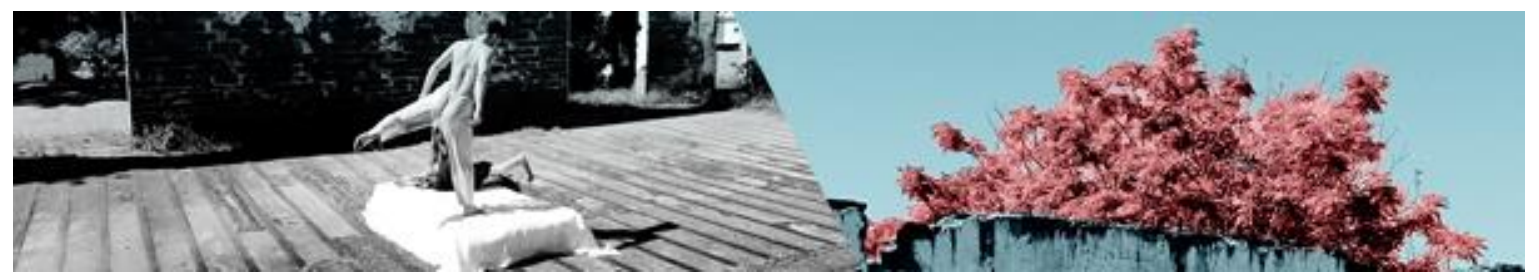

corpo que ele acredita que está no outro. Através da investigação corporal, pude ver os estudantes se surpreenderem com algo que já possuíam, um corpo, mas o sistema dicotômico dita quais corpos habitamos nos espaços das salas aula. Por conseguinte, presenciei os conteúdos dialogando com as propostas das professoras regentes 1 e 2 (de Artes Visuais) e a aula foi ganhando potencialidade. Momentos em que os estudantes com seus corpos trouxeram suas próprias experivivências e assim se viram fazendo parte das aulas. E a cada aula ministrada no estágio, os corpos dos estudantes amparados pela teoria através da prática foram nos surpreendendo e os estudantes sendo surpreendidos por um saber-sentido nas aulas de Arte daquele contexto.

\section{O corpo do estudante em (re)significação epistêmica}

O processo de "escuta" do corpo cênico pedagógico dos estudantes nas aulas iniciou-se com a elaboração dos planos de aulas, partindo de uma epistemologia outra como proposta para movimentar os corpos através da linguagem da Dança. Após esta preparação, contendo as impressões que foram se revelando no delongar das aulas nas escolas, com a observação primeiro e depois com a prática docente, pude ver que os conteúdos aprendidos pelos estudantes ainda são de perspectiva tradicionalista. Porém, isso não impediu que as aulas se tornassem trocas de conhecimentos e conteúdos, pois, partindo de uma epistemologia outra, o saber foi sentido e apreendido por meio do corpo em movimento nos estudantes.

Deste modo, as aulas foram elaboradas promovendo aos estudantes, professores e outros envolvidos do ensino, a apreensão de que o ensino de Dança/Arte está para além de um saber estático. Diferente do que as escolas até hoje promovem, os corpos dos estudantes nas aulas devem si-mover-se. Para isso, a retomada dos conteúdos anteriores ministrados pelas professoras, durante 0 a realização do estágio supervisionado, foi essencial para o entendimento do corpo cênico pedagógico dos estudantes nas aulas e do diálogo entre os conteúdos de Artes Visuais e Dança (Artes Cênicas), que promoveu aos estudantes "saber[es ]

NORONHA, Marina Maura de Oliveira; BESSA-OLIVEIRA, Marcos Antônio.Corpos roubados nos saberes do ensino de Arte. Revista da FUNDARTE, Montenegro, p.417-437, ano 19, no 37 , Janeiro/Março.

Disponível em: http://.seer.fundarte.rs.gov.br/index.php/RevistadaFundarte/index> 30 de março de 2019. 


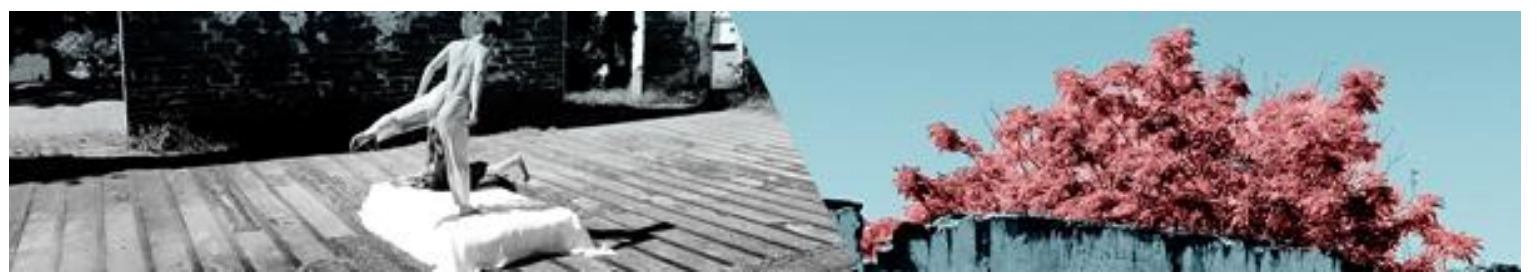

desterritorializad[os]" (HISSA, 2001, p. 28) no ensinar, no aprender e no praticar Arte/Dança na escola.

Por conseguinte, fora apresentado aos estudantes o reconhecimento do "seu corpo - essa casa onde [ele] não mora" (BERTHERAT, 2010, p. 1) e que por ele ainda assim é compreendido. Por meio de estímulos e propostas pedagógicas outras, os estudantes iniciaram suas expressividades corporais levando à criação da sua própria dança. Isto posto, o corpo já desvinculado do corpo enrijecido das "cadeiras" também passou a ser compreendido.

O corpo cênico pedagógico refletiu nos corpos dos estudantes nas aulas. Com as turmas do $6^{\circ}$ ano da professora 1 , durante as aulas do estágio, os estudantes foram provocados através do conteúdo de História da Arte (Artes Visuais) para a construção do corpo primitivo através da linguagem da Dança. Diante das propostas apresentadas (Imagem 1) a intenção foi abrir novas possibilidades para que o estudante, apreendendo, dialogasse melhor com seu corpo diante da complexidade dos saberes, e que compreendesse que o seu corpo também produz conhecimento dentro e fora das salas de aula. O corpo-imagem cênico pedagógico do estudante, atravessado por pensamentos outros, proporcionou imagens do corpo primitivo em seus corpos, mas dentro das suas especificidades corporais contemporâneas.

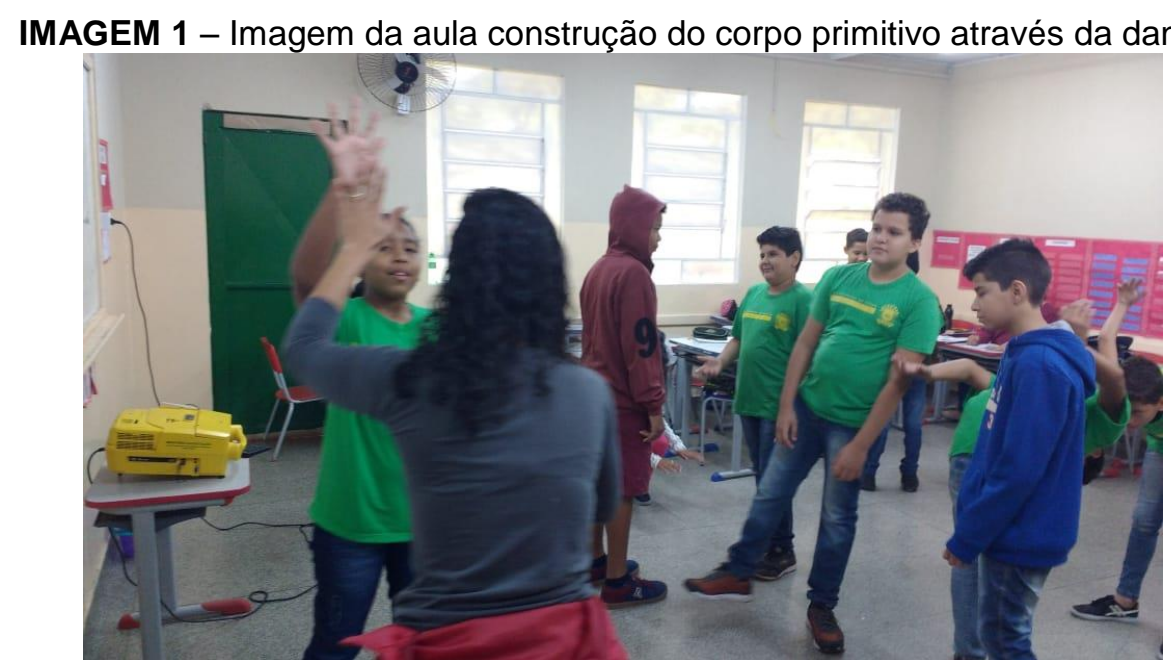

Fonte: Acervo da autora da Pesquisa.

NORONHA, Marina Maura de Oliveira; BESSA-OLIVEIRA, Marcos Antônio.Corpos roubados nos saberes do ensino de Arte. Revista da FUNDARTE, Montenegro, p.417-437, ano 19, no 37, Janeiro/Março.

Disponível em: http://.seer.fundarte.rs.gov.br/index.php/RevistadaFundarte/index> 30 de março de 2019. 


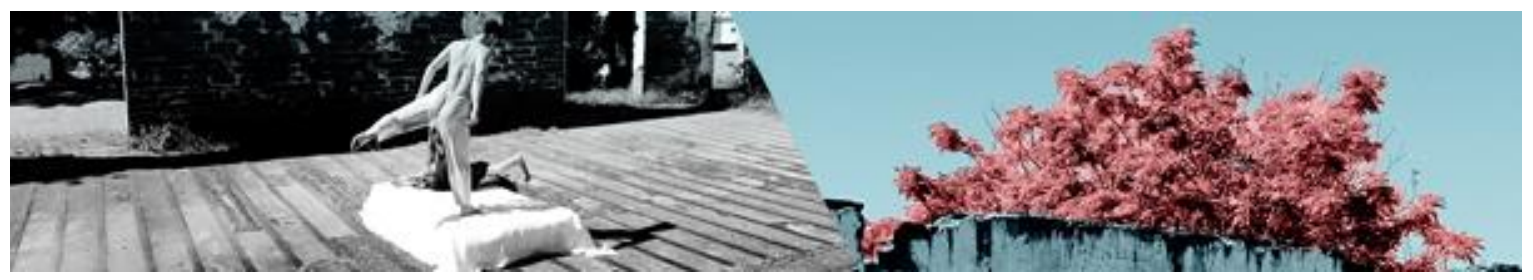

Outro aprendizado importante com o corpo cênico pedagógico no estágio se deu com os estudantes do $3^{\circ}$ ano do ensino médio da professora 2 . Os estudantes apreciaram o primeiro contato com a dança, através das Artes Cênicas na escola, a partir de um olhar de estranheza, já que o ensino ainda reflete o pensamento cartesiano que separa a emoção da razão em suas metodologias. Propondo perspectivas outras, conforme se apresenta na imagem 2, os corpos dos estudantes junto ao meu corpo docente configuraram-se no corpo-imagem cênico-pedagógico a partir de suas próprias propostas práticas. Primeiramente, se valendo da prática do jogo coreográfico, com o intuito de que experienciassem a criação a partir de frases de movimentos, os estudantes criaram. O corpo do estudante para o estágio supervisionado não "buscava ensinar e educar "corpos conchas" (MARQUES, 2001, p. 32), mas sim corpos criativos, humanos e não disciplinares; e, ainda mais, corpos que estão em constante sintonia com as reformulações do tempo contemporâneo: dinâmico, rápido e muito instável.

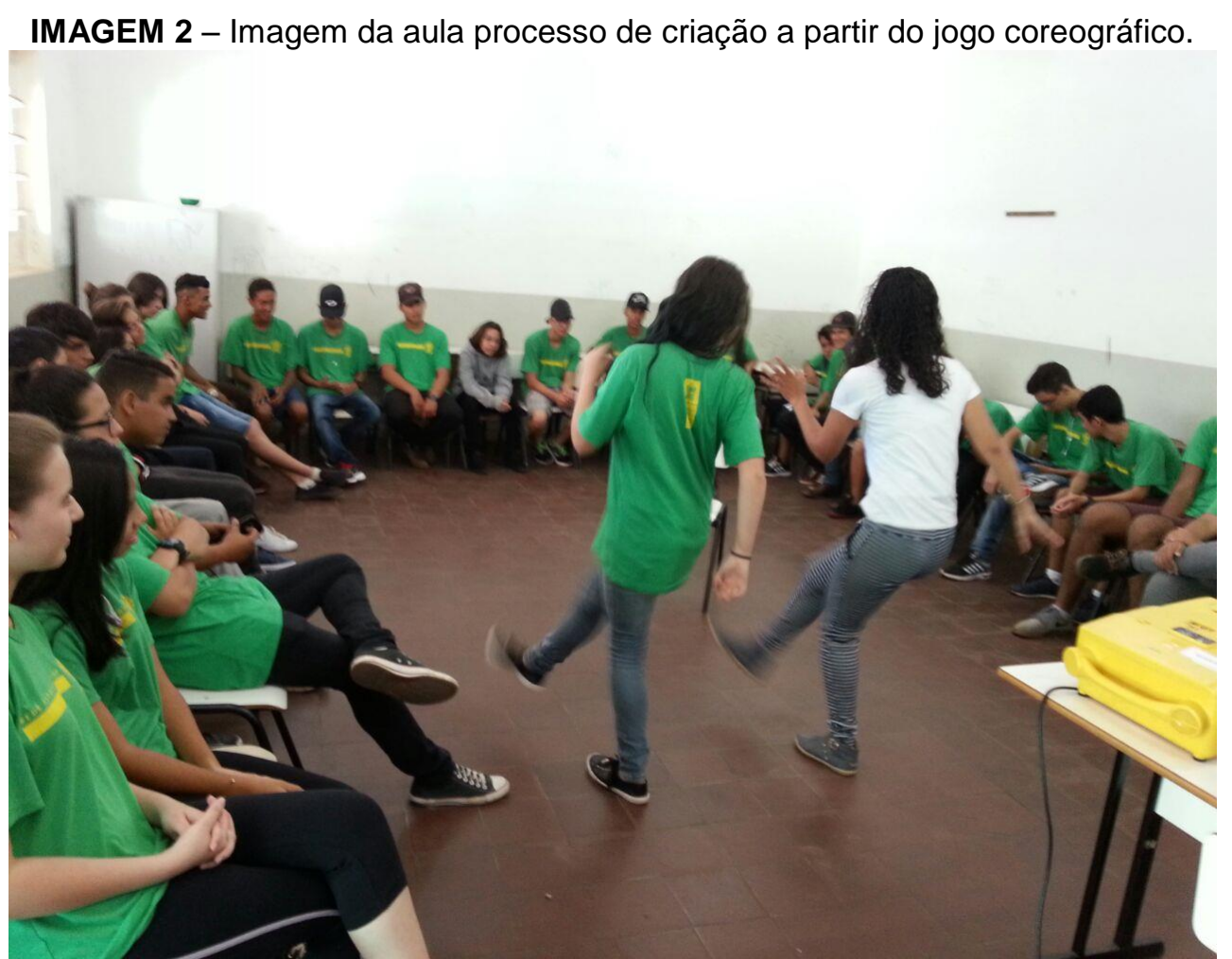

Fonte: Acervo da autora da pesquisa.

NORONHA, Marina Maura de Oliveira; BESSA-OLIVEIRA, Marcos Antônio.Corpos roubados nos saberes do ensino de Arte. Revista da FUNDARTE, Montenegro, p.417-437, ano 19, no 37, Janeiro/Março.

Disponível em: http://.seer.fundarte.rs.gov.br/index.php/RevistadaFundarte/index> 30 de março de 2019. 


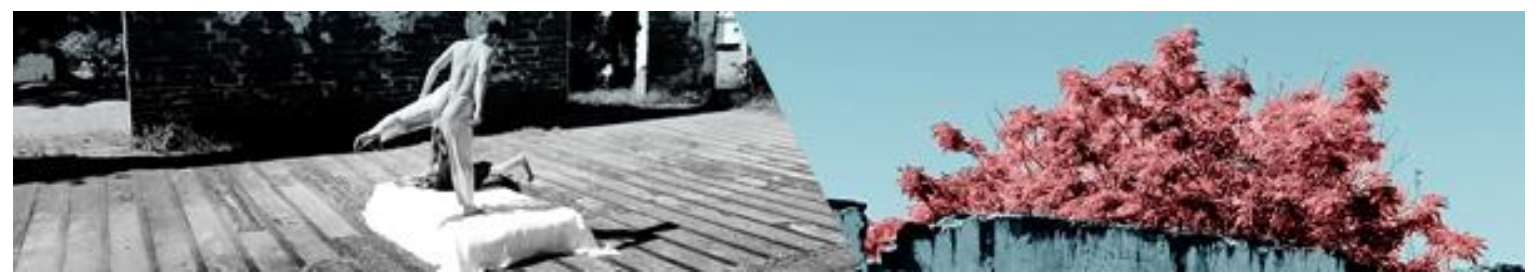

Ligia Tourinho explica sobre o surgimento na escola do jogo coreográfico que "foi introduzido pedagogicamente através de exercícios de espelho, que consiste em um trabalho em dupla: um propõe e outro imita" (TOURINHO, 2007, p. 01). Não na imitação fiel, mas no seguir os rastros do movimento deixado pelo outro no espaço da dança, por exemplo. Através das práticas do jogo coreográfico os corpos dos estudantes foram se construindo em frases de movimentos atravessados pelas relações com o colega, com outras duplas, com o olhar, com o toque transmitindo a sensibilidade do aprendizado em si e no outro.

Do percurso com a prática do jogo coreográfico, a meu ver, o estudante corporeografou-se diante da proposta, atravessado pela ideia epistêmica do corpo cênico-pedagógico, um corpo pensado nos estudantes, considerando suas vivências "[...] de fora desses muros: o que os alunos trazem consigo, dentro dele e viceversa" (BESSA-OLIVEIRA, 2010, p. 139). Dessa forma, ficou entendido qual dança o corpo do estudante sabe dançar, seja dentro ou fora da escola, bem como em qualquer outro lugar que o corpo queira flexionar-se. Pois, afinal, esse não é um corpo sentado estático.

Embasado por estes questionamentos do corpo que dança e que si-move-se dentro e fora da escola, o corpo cênico-pedagógico do aluno - biogeográfico - tem muito a contribuir para esse novo olhar no campo dos saberes. Portando, o objetivo maior é romper com as fronteiras que se estabelecem na prática, na teoria e na pesquisa em artes, que definem a ciência como único e exclusivo lugar de produção de conhecimento, ou seja, ficando assim entendido que os corpos dos saberes só são válidos se forem cientificamente confirmados em padrões estabelecidos. Contribuindo com a abordagem Ramón Grosfoguel afirma que:

Contudo, a análise do sistema-mundo não encontrou uma maneira de incorporar os saberes subalternos nos processos de produção de conhecimento. Sem isto não pode haver uma descolonização do conhecimento nem uma utopística capaz de superar o eurocentrismo. A cumplicidade entre as ciências sociais e a colonialidade do poder na produção de conhecimento e dos desenhos imperiais globais requer novos lugares institucionais e não-institucionais, a partir dos quais o subalterno possa falar e ser ouvido. (GROSFOGUEL, 2008, p. 71).

NORONHA, Marina Maura de Oliveira; BESSA-OLIVEIRA, Marcos Antônio.Corpos roubados nos saberes do ensino de Arte. Revista da FUNDARTE, Montenegro, p.417-437, ano 19, ํo 37, Janeiro/Março.

Disponível em: http://.seer.fundarte.rs.gov.br/index.php/RevistadaFundarte/index> 30 de março de 2019. 


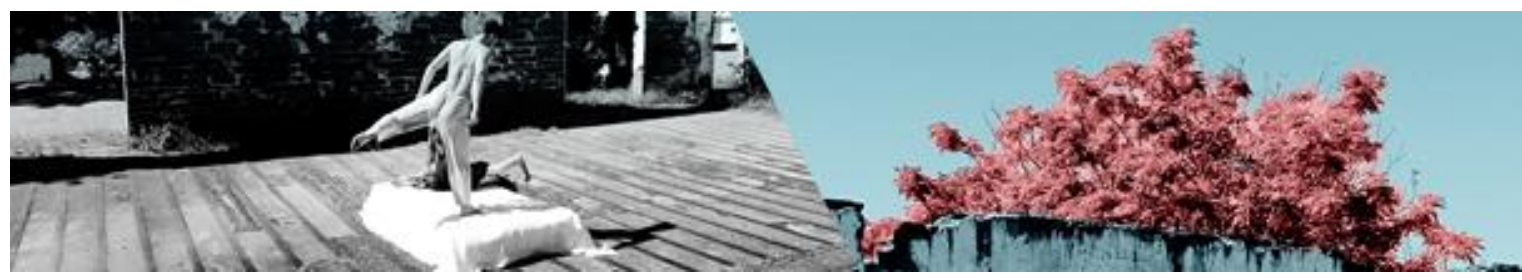

Igualmente, portanto, a ideia dessa pesquisa é fazer ressaltar que o corpo subalterno do corpo cênico-pedagógico ${ }^{16}$ dos estudantes também produz arte, cultura e conhecimento, exatamente de onde ele(s) quer(em) si-mover(em)-se. Mas, nesse sentido, é preciso compreender que estarão em xeque os conceitos de arte, cultura e conhecimento estabelecidos na cultura ocidental, assim como os conceitos de corpo, escola, estudante, professor e, porque não, de dança, teatro, música e até de artes visuais, já que falamos de ensino de Arte.

\title{
Considerações finais
}

\begin{abstract}
Hoje diríamos que mais que "nos modernizar" a orientação é para "nos naturalizar". Isto é, na medida em que o discurso constitutivo da modernidade separou ser humano e natureza, cultura e natureza, e nos fez esquecer que somos (nossos corpos necessitam de água e alimentos) natureza. (MIGNOLO, 2017, p. 26).
\end{abstract}

A fim de concluir, a partir do que fora apresentado - mesmo tendo em vista que não é possível parar e concluí-lo totalmente por aqui -, nesta pesquisa busquei discorrer como se deu o percurso de realização do estágio supervisionado obrigatório do Curso de Artes Cênicas - Licenciatura da UEMS - nos anos de 2017 e 2018 por mim realizados. Atividades que trouxeram questões bastante válidas para pensar o ensino de Arte na atualidade; e não apenas o ensino de uma linguagem única. Com a experiência, propus para as aulas no estágio o objeto dessa pesquisa - o conceito do corpo cênico-pedagógico construído por mim e meu orientador ao longo dos últimos quatro anos, pensado para os estudantes como epistemologia outra para o ensino-aprendizagem (a troca) para as aulas de Arte. Através dessa experivivência no âmbito das escolas de Mato Grosso do Sul foi possível (re)significar corpos outros nas aulas, partindo dessa epistemologia outra em que os corpos dos estudantes fora conduzidos, pelo viés das Artes Cênicas, e

\footnotetext{
${ }^{16}$ Através da temática dessa pesquisa que tem como objeto o corpo cênico pedagógico, visando ao mestrado, o corpo será referenciado agora como um corpo cênico biopedagógico por orientação do Prof. Dr. Edgar Cezar Nolasco que concluiu se tratar de um corpo epistêmico.
}

NORONHA, Marina Maura de Oliveira; BESSA-OLIVEIRA, Marcos Antônio.Corpos roubados nos saberes do ensino de Arte. Revista da FUNDARTE, Montenegro, p.417-437, ano 19, № 37, Janeiro/Março.

Disponível em: http://.seer.fundarte.rs.gov.br/index.php/RevistadaFundarte/index> 30 de março de 2019. 


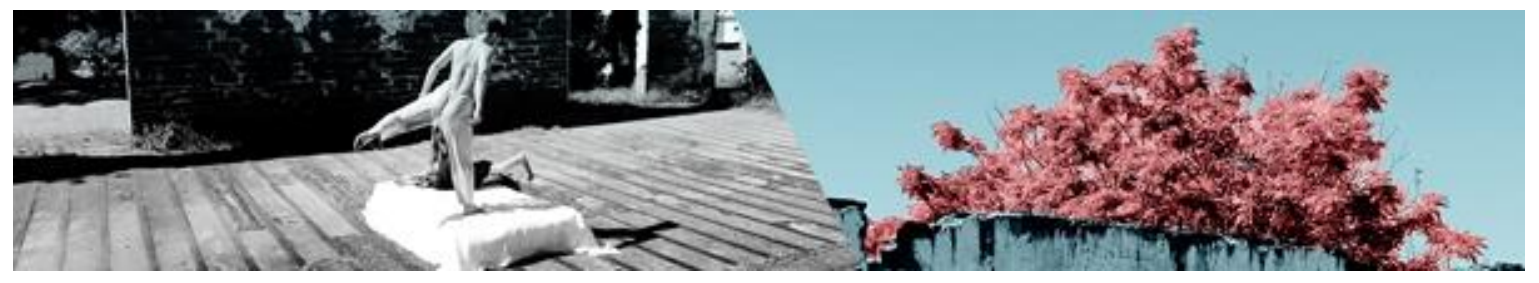

sendo estimulados a si-moverem-se (BESSA-OLIVEIRA) através das suas especificidades nos espaços da sala de aula na disciplina de Arte.

Portanto, partindo dessas perspectivas e considerando o corpo do estudante, atravessado pela sua subjetividade do corpo sempre, afirmo que foi um caminho significativo para esses corpos se movimentarem, seja aprendendo-dança, praticando-dança ou seja ensinando-dança nas aulas de Arte (entendam-se esses verbos em sentidos de trocas entre estudantes e professora estagiária). O corpo ressaltado aos estudantes sendo o corpo cênico-pedagógico fez construções de conhecimentos outros. Ou seja, a ideia de inscrição daqueles corpos como corpos do contra - modelo - é exatamente a fim de fazer situar minhas discussões teóricas no campo da prática como contraposição ao discurso moderno que toma todo e qualquer corpo disciplinado como modelo. Por isso, penso que ainda há muito a se discutir no cenário das artes, especialmente sobre o corpo que dança na aula de Arte. Conforme presenciei com o corpo no estágio supervisionado, os corpos que transitam nos espaços da escola ainda trazem a rigidez e a insistência imperante da modernidade (são os mesmos corpos de fora das escolas, dentro dela, pois ali passam a ser enrijecidos pela disciplina), visto que ainda somos corpos colonizados reprimidos pelas/nas diferenças nos/dos espaços da escola da contemporaneidade. Mas nunca os corpos da escola serão os mesmos corpos que transitam nas (fronteiras) ruas das cidades. (RE)existência é NATURALIZAR-SE!

\section{Referências:}

BERTHERAT, Thérèse. O corpo tem suas razões: antiginástica e consciência de si. Com colaboração de Carol Bernstein; tradução Estrela dos Santos Abreu. 21ạ . Ed. São Paulo: Editora WMF Martins Fontes, 2010.

BESSA-OLIVEIRA, Marcos Antônio. "Fronteira, biografia - biogeografias - como episteme descolonial para (trans)bordar corpos em artes da cena". In: Revista Conceição/Concept. Campinas, SP, v. 7, n. 1, jan./jun. 2018, p. 142-157. Disponível em:

https://periodicos.sbu.unicamp.br/ojs/index.php/conce/article/view/8648471/18307.

Acesso em: 03/08/2018.

NORONHA, Marina Maura de Oliveira; BESSA-OLIVEIRA, Marcos Antônio.Corpos roubados nos saberes do ensino de Arte. Revista da FUNDARTE, Montenegro, p.417-437, ano 19, no 37, Janeiro/Março.

Disponível em: http://.seer.fundarte.rs.gov.br/index.php/RevistadaFundarte/index> 30 de março de 2019. 


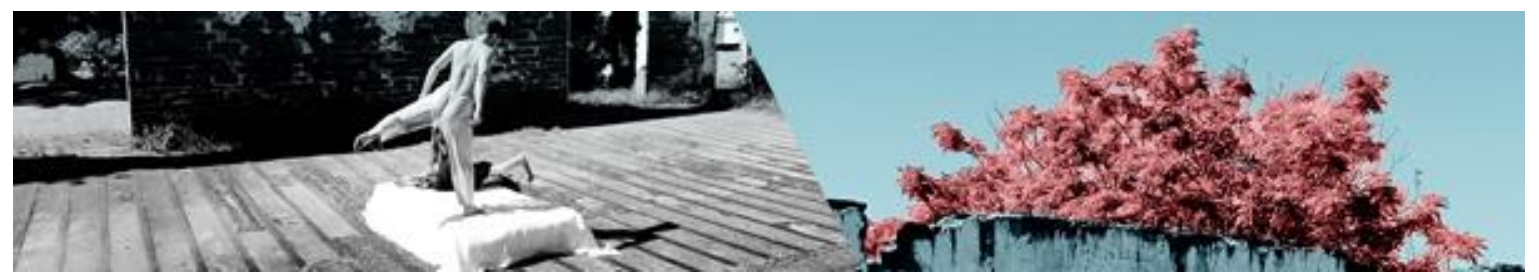

BESSA-OLIVEIRA, Marcos Antônio. "Corpos" da exterioridade nas arte visuais: processos criativos barrados por/em fronteiras". In: Disciplina de Artes Visuais - texto-tema das aulas de Artes Visuais do $1^{\circ}$ ano da Graduação do Curso de Artes Cênicas - UEMS - Universidade Estadual de Mato Grosso do Sul - UUCG - Unidade Campo Grande. Campo Grande, MS, 2018, p.1-. (Texto no Prelo)

BESSA-OLIVEIRA, Marcos Antônio. "(Trans)bordar fronteiras: estética bugresca para descolonizar corpos biogeográficos". In: Memória Abrace XVI - Anais do Congresso da Associação Brasileira de Pesquisa e Pós-Graduação em Artes Cênicas. Anais... Uberlândia (MG), UFU, 2017, p. 4.493-4.518. Disponível em: https://www.even3.com.br/anais/IXCongressoABRACE. Acesso em: 29 de junho de 2018.

BESSA-OLIVEIRA, Marcos Antônio. "Biogeografias Ocidentais/Orientais: (i)migrações do bios e das epistemologias artísticas no front". In: Cadernos de Estudos Culturais: Ocidente/Oriente: migrações. V. 8. N. 15. Campo Grande, MS: Ed. UFMS, jan.- jun., 2016, p. 97-144.

BESSA-OLIVEIRA, Marcos Antônio. Ensino de Arte $X$ Estudos Culturais: para além dos muros da escola. São Carlos, SP: Pedro \& João Editores, 2010.

BESSA-OLIVEIRA, Marcos Antônio; NORONHA, Marina Maura de Oliveira. "O mundo a partir de fronteras do fim do mundo - Brasil/Paraguai/Bolívia - teoria da arte descolonial". Cadernos de Estudos Culturais: BRASIL/PARAGUAI/BOLÍVIA. Campo Grande, v. 7, n. 14, jul. - dez., 2015, p. 65-102.

BESSA-OLIVEIRA, Marcos Antônio. Ensino de Arte $X$ Estudos Culturais: para além dos muros da escola. São Carlos, SP: Pedro \& João Editores, 2010.

BRASIL. MEC. Lei de Diretrizes e Bases da Educação Nacional - LDB 9.394/1996. Brasília, $1996 . \quad$ Disponível em: http://portal.mec.gov.br/seesp/arquivos/pdf/lei9394 Idbn1.pdf. Acesso em: 05/04/2018.

DANTAS, Mônica. Dança: O enigma do movimento. Porto Alegre. Ed. Universidade/UFRGS, 1999.

FOUCAULT, Michel. Vigiar e Punir: nascimento da prisão. Trad. Lígia M. Ponde Vassalo. Petrópolis: Vozes, 1987.

GROSFOGUEL, Rámon. "Para descolonizar os estudos de economia política e os estudos pós-coloniais: Transmodernidade, pensamento de fronteira e colonialidade global". Tradução de Inês Martins Ferreira. In: Revista Crítica de Ciências Sociais, 80 / 2008, p. 41-91. Disponível em: https://journals.openedition.org/rccs/697 - Acesso em: 06/09/2018.

NORONHA, Marina Maura de Oliveira; BESSA-OLIVEIRA, Marcos Antônio.Corpos roubados nos saberes do ensino de Arte. Revista da FUNDARTE, Montenegro, p.417-437, ano 19, № 37, Janeiro/Março.

Disponível em: http://.seer.fundarte.rs.gov.br/index.php/RevistadaFundarte/index> 30 de março de 2019. 


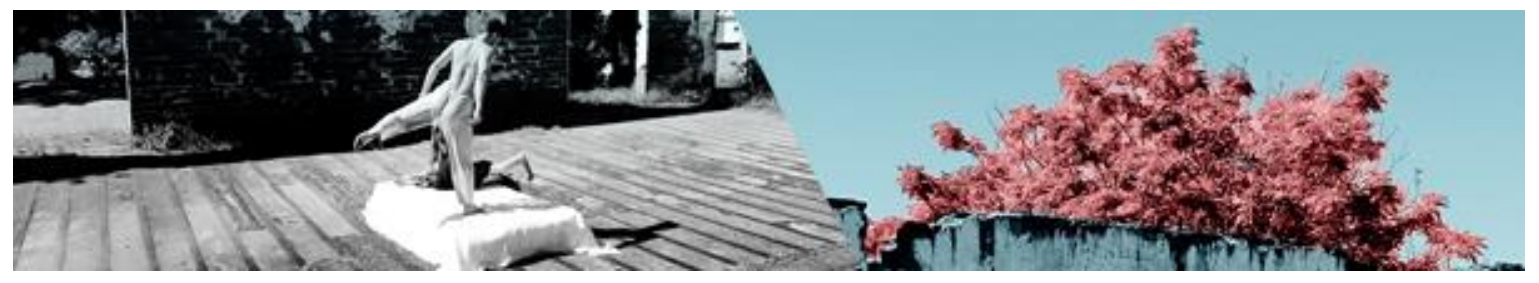

GREINER, Christine. "Em busca de uma metodologia para analisar a alteridade na arte”. In: Conceição I Concept. Campinas, SP, v. 6, n. 2, p. 10-21, jul./dez.2017. Disponível em: https://periodicos.sbu.unicamp.br/ojs/index.php/conce/issue/view/1417/showToc. Acesso em: 06/11/2018.

HISSA, Cássio E. Viana. (Org.). Conversações: de artes e de ciências. Belo Horizonte: Editora UFMG, 2011. (Humanitas).

HISSA, Cássio Eduardo Viana; RIBEIRO, Mônica Medeiros. "Saber Sentido". In: Conceição I Concept. Campinas, SP, v. 6, n. 2, jul./dez. 2017, p. 90-109. Disponível em: https://periodicos.sbu.unicamp.br/ojs/index.php/conce/issue/view/1417/showToc. Acesso em: 15/09/2018.

LABAN, Rudof. Domínio do movimento. Edição organizada por Lisa Ullmann. Tradução: Anna Maria Barro De Vecchi e Maria Silva Mourão Netto; revisão técnica: Anna Maria Barros De Vecchi. São Paulo: Summus, 1978.

MARQUES, Isabel. Corpo, dança e educação contemporânea: Pro-posições - Vol. 9 $N^{\circ} 2$ (26) Junho de 1998.

. Dançando na escola. São Paulo: Cortez, 2003.

MENCARELLI, Fernando. "Epistemologias: transversalidades nas artes da cena". In: Conceição I Concept. Campinas, SP, v. 6, n. 2, p. 5-9, jul./dez. 2017. Disponível em: https://periodicos.sbu.unicamp.br/ojs/index.php/conce/issue/view/1417/showToc.

Acesso em: 06/07/2018.

MILLER, Jussara. "O corpo presente: uma experiência sobre dança-educação". In: ETD - Educ. Temát. Digit. Campinas, SP, v. 16, n. 1, jan./abr. 2014, p. 100-114. Disponível

em: https://periodicos.sbu.unicamp.br/ojs/index.php/etd/article/view/1332/1347. Acesso em: 15/08/2018.

MIGNOLO, Walter. "Desafios decoloniais hoje". In: Epistemologias do Sul. Foz do Iguaçu/PR, 1 (1), 2017, pp. 12-32. Disponível em: https://revistas.unila.edu.br/epistemologiasdosul/article/download/772/645

acessado em $22 / 11 / 2018$.

NELSON, Cary; TREICHLER, Paula A.; GROSSBERG, Lawrence. "Estudos Culturais: uma introdução". In: SILVA, Tomaz Tadeu da (Org.). Alienígenas na sala de aula. Petrópolis: Vozes, 1995, p. 7-24.

NORONHA, Marina Maura de Oliveira; BESSA-OLIVEIRA, Marcos Antônio. "Entre gingas e gingados: o corpo e a bovinocultura em cena na arte educação". In:

NORONHA, Marina Maura de Oliveira; BESSA-OLIVEIRA, Marcos Antônio.Corpos roubados nos saberes do ensino de Arte. Revista da FUNDARTE, Montenegro, p.417-437, ano 19, no 37, Janeiro/Março.

Disponível em: http://.seer.fundarte.rs.gov.br/index.php/RevistadaFundarte/index> 30 de março de 2019. 


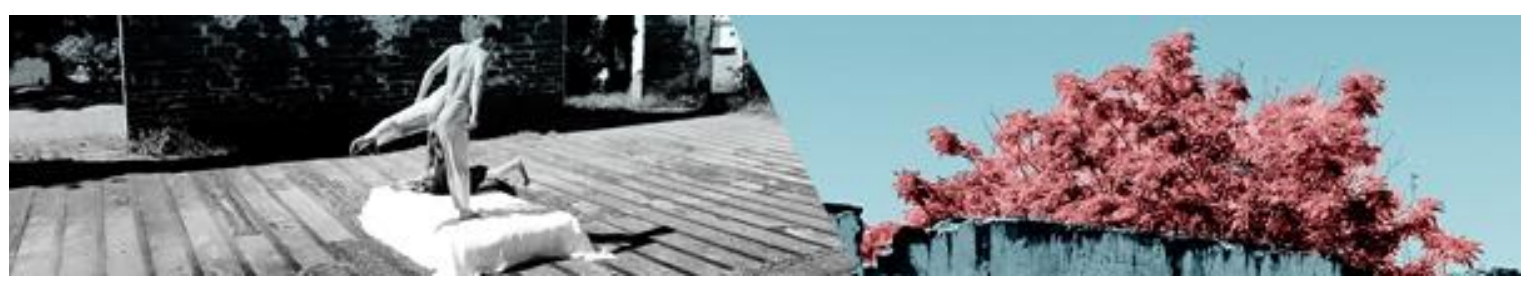

BESSA-OLIVEIRA, Marcos Antônio. (Org.). NAV(r)E - Pesquisa e produção de conhecimento em arte na universidade: artista, professor, pesquisador 2015/2016. Campo Grande, MS: Life Editora, 2018, p. 159-175.

STRAZZACAPPA, Marcia. Dança na educação. Discutindo questões básicas e polêmicas. In: Pensar a Prática no. 6., Jul./Jun., p. 73-85. 2002-2003. Disponível em: https://www.revistas.ufg.br/fef/article/view/55/54. Acesso em: 08/03/2018.

"A educação e a fábrica de corpos: a dança na escola". In: Cadernos Cedes. vol. 21. n. 53. Campinas, abr, 2001, p. 69-83. Disponível em: http://www.scielo.br/scielo.php?script=sci arttext\&pid=S0101-32622001000100005,acessados em: 22/10/2018.

TOURINHO, Lígia. "O Jogo Coreográfico". In: Anais da IV Reunião Científica de Pesquisa e Pós-Graduação em Artes Cênicas. V. 8, n. 1. Rio de Janeiro, 2007. p 14. Disponível em: http://www.publionline.iar.unicamp.br/index.php/abrace/article/view/1202/1300 Acessado em: 29/10/2018.

NORONHA, Marina Maura de Oliveira; BESSA-OLIVEIRA, Marcos Antônio.Corpos roubados nos saberes do ensino de Arte. Revista da FUNDARTE, Montenegro, p.417-437, ano 19, ㄲo 37, Janeiro/Março.

Disponível em: http://.seer.fundarte.rs.gov.br/index.php/RevistadaFundarte/index> 30 de março de 2019. 